\title{
Pesantren for elderly: Study of the spiritual empowerment of elderly women in Pondok Sepuh Payaman, Magelang
}

\author{
Dwi Agustina ${ }^{1^{*}}$
}

${ }^{1}$ Department of Sociology, Universitas Gadjah Mada, Indonesia

"Corresponding author

E-mail address: dwiagustina538@gmail.com

DOI: https://doi.org/10.21107/sml.v3i1.7356

\begin{tabular}{|c|c|}
\hline Article Info & Abstract \\
\hline $\begin{array}{l}\text { Keywords: } \\
\text { Spiritual } \\
\text { empowerment } \\
\text { Elderly } \\
\text { Dead } \\
\text { Anxiety } \\
\text { Islamic boarding } \\
\text { school }\end{array}$ & $\begin{array}{l}\text { This study aims to determine the spiritual empowerment in Sepuh Payaman } \\
\text { Cottage, Magelang. Spiritual empowerment is an effort to reduce the anxiety } \\
\text { of the elderly about death. In old age humans are often associated with death } \\
\text { that is getting closer. Preparing elderly mental health in the face of death is } \\
\text { a basic requirement for the community in addition to physical and social } \\
\text { health. In this study used a qualitative method approve case study, with } \\
\text { the process of collecting data using interviews and observations. In order to } \\
\text { analyze the data we used the disengagement theory of social gerontology. } \\
\text { The findings in this study that spiritual empowerment was carried out within } \\
24 \text { hours and framed through ritual and social worship. The teaching pattern } \\
\text { is emphasized in lecture-listening and learning by doing. The motivation of } \\
\text { the elderly and family support is a driving factor for the elderly, while the } \\
\text { decline in physical function is a limiting factor. In the pattern of spiritual } \\
\text { empowerment, implications are found including, 1) Obtaining inner peace; } \\
\text { 2) Getting closer to God; 3) Increasing the faith of the elderly; 4) Able to read } \\
\text { Al-Qur'an; 5) Growing humanity; and 6) Establishment of new relations. The } \\
\text { findings of this study can be used as an alternative and answer to reduce the } \\
\text { level of anxiety in the elderly related to death. }\end{array}$ \\
\hline
\end{tabular}

Citation suggestion:

Agustina, D. (2020). Pesantren for elderly: Study of the spiritual empowerment of elderly women in Pondok Sepuh Payaman, Magelang. Simulacra, 3(1), 43-55. https://doi.org/10.21107/sml.v3i1.7356

Received 29 May 2020; Received in revised form 4 June 2020; Accepted 5 June 2020; Published online 25 June 2020. 


\section{Introduction}

The elderly is an individual who has reached the age of 60 years and over (Kementerian Kesehatan, 2017). Data from the Central Statistic Body in 2018 revealed that the number of elderly people in Indonesia was increasing, from 7.3 per cent in 2010 to 8.9 per cent in 2017. The number is predicted to continue to increase until it reaches 10.8 per cent in 2020 (BPS, 2018). These phenomena do not only occur in Indonesia but also in various parts of the world. UNFPA (United Nations Population Fund) estimated that by 2050, one in five people in the world would be 60 years old. The elderly population would also exceed the population of children (UNFPA, 2009).

The increase in the number of elderly along with an increase in life expectancy is also an indicator of success in the development of a country (Ryadi, 2016). However, if the increase in the elderly is not balanced with a good quality of life, it will add to the problem for the elderly (Sufa, 2013). Elderly mental health is a basic need that must be promoted besides physical and social health (Parkar, 2015). In old age, the elderly may experience mourning which also affects their mental health (Yasamy et al., 2013). Mak's 2004 research findings revealed that 32 per cent of elderly suicide rates are caused by anxiety and depression $(\mathrm{Su}, \mathrm{H}$. et al., 2018). Mourning and death are indeed something that is feared by some elderly people (Santosa \& Ismail, 2009). Therefore, special treatment is needed to maintain the mental health of the elderly. One of them is by providing spiritual empowerment to the elderly.

Jalaluddinexplained that the 'resignation' method (full spiritual submission to God) is necessary to reduce anxiety in the elderly (Jalaluddin, 2011). Likewise, Maslow emphasized that religion makes elderly life more integrated (Sunaryo et al., 2015). Being involved with religion during old age is an important tradition to gain inner peace. Another study found that if the elderly does not show a form of surrender to God, they are more likely to experience a sense of insignificance (Dewi, 2014). Furthermore, social release theory believed that the elderly should choose to concentrate their oncoming death and withdraw from previous activities (Hillier \& Barrow, 2010).

Based on relinquishment theory, withdrawal from previous activities and putting the focus on the coming of death may help the elderly to avoid depression and anxiety. This theory is supported by Erikson, who also emphasized that the elderly does not need to maintain their old activities to maintain a higher level of self-esteem in their old age. Instead, the elderly only need to choose where their priorities are and withdraw from unnecessary relationships to focus on a more transcendent view (a view of God) (Rani \& Usha, 2018). Religion can function as a buffer of stress and can help one overcome certain events to improve one's spirituality (Stolley \& Koenig, 1997). Based on that viewpoint, this study attempted to find out the process and implications of spiritual empowerment carried out by Pondok Sepuh in Payaman, Magelang in maintaining the mental health of the elderly.

\section{Method}

This study used a qualitative method with a case study approach. The case study approach is suited to answer questions that require researcher to go deeper and obtain answers to research questions by exploring and elaborating (Rahardjo, 2017). In this study, researcher conducted the first step by collecting data through literature reviews, observations, and in-depth interviews. Next, researcher conducted data analysis and data interpretation using social gerontology theory. Data interpretation was made by 
narrating the finding data into a patterned story.

This research was conducted in a pesantren for the elderly, which was located in Masjid Agung (grand mosque) called Pondok Sepuh. Data collection was carried out in 2018. Researcher used selective informant technique and worked with key informants who were the caregivers in Pondok Sepuh. The key informants led researcher to interview four other caregivers in Pondok Sepuh. To support the research data, researcher also interviewed five elderly santri (student) who were selected using the purposive sampling method. Besides, researcher also interviewed the families of the santri using incidental sampling techniques. In this case, researcher interviewed santri families who happened to be at the study site.

Data analysis was performed using four steps - first, data collection, which was done through observation, interviews, and literature studies process. Second, the data are sorted according to the research's needs. Third, presenting and analyzing data based on research questions. Fourth, draw the conclusions.

\section{Results and Discussion}

\section{The History and Establishment of Pondok Sepuh}

The establishment of Pondok Sepuh in Payaman, Magelang was inseparable from the figure of $\mathrm{KH}$ Anwari Siradj or Mbah Siradj. Mbah Siradj was also the founder of Masjid Agung (grand mosque) Payaman, which was located inside the Pondok Sepuh complex. The establishment of Pondok Sepuh was initiated from the thought of Mbah Siradj at around 1953. Pondok Sepuh was established as a means of dawah and religious experiences for the elderly. The Payaman community were enthusiastic and fully supported Mbah Siradj's yearning to teach religions, specifically Islam, for the elderly. Encouraged by this, Mbah Siradj built a small building complex at the corner of the mosque which was named Pondok Sepuh.

Just after Mbah Siradj passed away, in 1959, his son KH. Ghozin, replaced him as the leader of Pondok Sepuh until 1975. In turn, KH Ghozin's son, KH. Syakir Ghozin succeeded him from 1975 to 2006. Pondok Sepuh experienced quite a progress in the era of KH. Syakir Ghozin. Researcher noted that Pondok Sepuh added evening prayers and pesantren kilat (express religious course) every Ramadan in which santri from various regions in Indonesia participated.

\section{Characteristics of Pondok Sepuh Payaman Magelang}

Pondok Sepuh was mainly known for its role in giving and instilling religious values to elderly santri (santri). Such is the main characteristic of pesantren or Islamic boarding schools. Based on observation and interview with the informant, researcher categorized the primary characteristics of Pondok Sepuh into the role of the Kyai or clerics, the curriculum, learning methods, the condition of the Pondok or house, the funding, and the religious orientation of the pesantren.

First, based on its primary characteristics, Pondok Sepuh was a Salafi and traditional pesantren. In terms of learning, Pondok Sepuh maintained learning patterns that emphasized religious value. The second primary characteristic was the role of the Kyai. Aside from being a religious figure, the Kyai of Pondok Sepuh also played a significant role in guiding and motivating santri to behave and act following Islamic teachings. Besides, the Kyai of Pondok Sepuh laid the example to the santri to do good deeds. The third fundamental characteristic 
was the curriculum. Pondok Sepuh was a pesantren that still retains its traditional curriculum, which was not the standard government curriculum. The pesantren used curriculum tailored to the needs of santri. Pondok Sepuh preached about behaviors that rescind prayers, procedures for ablution and prayer, and so forth.

The fourth characteristic was the learning method. In Pondok Sepuh, spiritual empowerment teachings were delivered using methods that made it easier for santri to understand. This learning method was adapted to the conditions of elderly santri. Therefore, learning processes were mostly conducting using nguping method or 'eavesdropping' as well as lectures and learning by doing. Fifth, the learning resources. Considering that the santri at Pondok Sepuh were mostly over 60 years old, the learning resources used were mainly the lectures from Kyai and Nyai (female Kyai). Sixth, the condition of the pesantren. Physically, Pondok Sepuh consisted of the Kyai's houses, mosques, rooms, kitchens, and areas for bathing, washing, and toilet. The kyai's house and the mosque were used for the transfer of knowledge. The learning process took place at Masjid Agung Payaman while the Kyai's house hosted Iqra and Quran recitation activities.

Seventh, the funding. Most of the funding sources in Pondok Sepuh still came from the infaq from the mosque, the santri, and pilgrims who came to the tomb of Kyai Siradj which is located behind the Masjid Agung Payaman. All expenditures for the mosque and the pesantren, such as electricity, water, repair of facilities and infrastructure were taken from the infaq (donation) from the mosque, santri and pilgrims. Eighth, Pondok Sepuh's religious orientation. The motto of Pondok Sepuh, which was "The spirit of worship for provision in the barzah world (afterlife)," illustrated that Pondok
Sepuh aimed to prepare elderly santri to welcome their death by providing religious knowledge to santri. This preparation was done to help santri gain inner peace and blessing from Allah Ta'ala (God Almighty).

\section{Pondok Sepuh as a New Social Space for the Elderly}

From interviews with caregivers, researcher found that several reasons that caused Pondok Sepuh to become an elderlyfriendly social space. First, the pesantren's environment supported the existence of elderly people. This conclusion was based on the sheer number of elderly people living around the pesantren complex. Second, there was freedom for santri to choose whether or not to take part in activities. There was no mandatory regulation from the boarding school. Therefore, santri participations were based on their awareness of their religious needs. Third, there was no compulsion for the elderly to live in the pesantren complex. The management did not limit how long a santri must stay in the pesantren or leave the pesantren. All activities were carried out based on the santri's awareness and needs.

The sheer number of elderly people studying religious knowledge at Pondok Sepuh was also one indicator that it could reduce the level of anxiety in the elderly. In Pondok Sepuh, the elderly could establish interactions with others to their lives together with a community that has the same goals and ideals. This was supported by a report from UNFPA (United Nations Population Fund) which stated that as people age, their mental health is increasingly vulnerable due to decreased physical and social functioning. Therefore, according to UNFPA, as people get older, they must live in their communities to maintain the spirit and live the rest of their lives. 
Supporting and Inhibiting Factors of Spiritual Empowerment in Pondok Sepuh

Several factors support and inhibit the formation of spiritual empowerment in Pondok Sepuh. Supporting factors were composed of internal and external factors. Internal factors were factors that originate from within the individual. Meanwhile, external factors originated from outside of the individual.

Internal factors that supported spiritual empowerment include: 1) the santri's aspiration due to lack of understanding of religious knowledge, 2) caring for grandchildren at home due to no decreasing activities, 3) the yearning of blessings from the Romo Agung or 'great father' (the founder of Pondok Sepuh and Masjid Agung Payaman), and 4) the wish to die in a husnul khotimah state (good ending). The following informants illustrated such yearning:

\section{"Before she died, my husband gave her will to our children. She wanted them to put me in pesantren so that I could learn worldly and heavenly Islamic teaching. Now, my husband is gone. Instead, my children told me to go to the pesantren so that I could learn about the afterlife, so in the end, I could reunite with my husband again. But, besides that reason, I came here because I wanted to gain the blessing from Romo Agung. I was only asked to look after my grandchildren at home. Yes, I choose here, free, gaining knowledge, learning the Quran" (interview of santri MD, 11 September 2018).}

In addition to internal factors, there were also external factors, namely the support of the family. Family support, in this case, can take material or non-material forms. Material support included money, food and clothing. Meanwhile, non-material support meant information, affection, and guidance or direction.
Social support is considered effective in reducing the level of anxiety in the elderly. A recent study by Kwon and Billiot revealed that elderly Americans who received social support from their neighbor had 0.03 lower depression rate than elderly people who did not get social support (Kwon \& Billiot, 2018). The inhibiting factor in spiritual empowerment in Pondok Sepuh came from the decline in physical function of the elderly. The decline in physical function was in the form of 1) decreasing vision and hearing; 2) declining memory, and 3) unclear pronunciation. The existence of these inhibiting factors did not become a problem for caregivers. The decline in physical function is indeed a natural and a sign of old life. Thus it is indeed time to improve oneself and return to the Creator. Sunaryo stated that as they get older, the elderly will experience a decline in physical, social, and mental function (Sunaryo et al., 2015).

\section{Process and Form of Spiritual Empowerment in Pondok Sepuh}

Spiritual empowerment in Pondok Sepuh was carried out for 24 hours in a day. Although there was a 24-hour learning pattern, it did not mean that santri must study for a full 24 hours. However, the 24hour learning pattern was made so that santri can decide their time to study. The santri were free to choose to join or not participate in an activity. There was no compulsion for santri to participate in all activities offered by the boarding school. The santri was only expected to be aware and follow the rules that they needed. Kyai TB stated: "There is no compulsion; it is free. Whether santri want to join the Quran recitation or not, is up to them. Old people cannot be forced. It will just make things even more difficult" (interview of Kyai TB, 7 September 2018).

The findings also showed that before becoming a santri, the elderly must go 
through several screening processes. This fact was revealed by the caregivers at Pondok Sepuh. First, santri must meet the requirements specified by the boarding school. First, only widowed women can join. They must be at least 60 years old, in good health, independent, and have a guardian. Second, the elderly must be accompanied by their family at their initial registration at the secretariat. Third, the elderly must pay a base of three hundred thousand rupiahs which is used to manage the mosque and pesantren. Until now, there were around 60 elderly santri living in Pondok Sepuh.

In addition, there were also other forms of spiritual empowerment at Pondok Sepuh. Empowerment activities were divided into two, namely ritual worship and social worship. Ritual worship or mahdhah (servitude) worship is a worship directly related to God or hablum minallah. Some of the activities at Pondok Sepuh included in ritual worships were the obligatory and sunnah prayer lessons, Al-Quran and Ibris book recitation lessons, fasting lessons, and Al-Quran studies.

Meanwhile, social worship or ghoiru mahdhah worship is the opposite of hablum minallah (relationship with God). It emphasises hablum minannas or relationship with a fellow human. Some social worship followed by santri includes: helping each other, sharing (shodaqoh) in the form of money or food, establishing a friendship, visiting and praying for the sick, as well as offering condolences when a neighbor or relative dies. In supporting spiritual empowerment emphasized on ritual and social worship, the pesantren management provided several lessons: 1) Iqra volume 1 to volume 6 for those who could not read the Quran; 2) Quran studies; 3) the book of Ibris studies; 4) materials related to the correct procedures for ablution and prayer; 5) collective dhikr; 6) morality and hadith lessons.
Other learning methods were also used for spiritual empowerment. Based on the interviews and observations, researcher identified several methods used in spiritual empowerment. First, lecture or 'eavesdropping.' This method was widely used by the Kyai when delivering lessons to santri. Second, the demonstration. This method was used to provide a correct example of worship practices. Third, question and answer. This method was used to promote interaction between the Kyai and santri in the lessons. Fourth, sorongan. This method is common in various boarding schools. In Pondok Sepuh, the sorongan method was also used during the Quran and Ibris book recitation. Fifth, the method berjanjen and wiridan. These methods prompt santri to develop the habit of dhikr to Allah and to pay tribute (sholawat) to Rasulullah. The last method was learning by doing. This method was a method in which santri learn while practising in their daily lives.

\section{Implications of Spiritual Empowerment in Pondok Sepuh}

The process of spiritual empowerment through by Pondok Sepuh also has several implications for the santri, including:

\section{Obtaining inner peace in the face of death}

Obtaining inner peace was one of the wishes of santri at Pondok Sepuh. They hoped to die in the state of Husnul Khotimah (good ending). It was the highest achievement desired by the santri at Pondok Sepuh. Santri ED, who was 65 years old, felt that she was happy to receive the guidance to live in Pondok Sepuh. She experienced a profound inner peace. She explained:

"I am happy to live here. I am in peace. I don't think about anything. It's different from home. The good thing is that here, one can get knowledge for the afterlife, can pray for my parents. My 
parents and I don't have the same religion. I used to be confused, I wanted to pray for them, but we have different religions. I thought, 'is it possible?' I talked to Bu Nyai. She said whether your prayers were accepted or not, I have to keep praying. Instantly, I was relieved, my heart miss. Number two, the friends here are all the same, at home we had nothing to do, we're tired of being told to take care of our grandchildren" (interview with santri ED, 11 September 2018).

Another experience came from a retired teacher, santri SR who was 72 years old. SR stated that death scared her because of her lack of religious knowledge. There was a sense of remorse in her heart for not studying religion in her youth. However, currently, SR was grateful for the guidance given by Allah. She also felt calmer in living the rest of her life. In fact, she hoped to continue to improve before God.

\section{Getting closer to the Creator}

Researcher observed that the santri's daily routine was mostly done to get closer to the Creator and was carried out for more than 12 hours. Spiritual empowerment activities carried out for 24 hours have spurred the spirit of the santri to carry out ritual and social worship in order to get the blessing of the Supreme Being. By being in the pesantren, santri feel closer to the Creator than at home. The testimony came from a 70-year-old santri; AM. AM was a seller who has lived in Pondok Sepuh for the past five years.

"Here, I am not tired if, at home, I am often tired. I had many things to do, and I never stood still in the house. I can't recite the Quran. In here is not tired, just focus on my worship. My job here is just eating, worshipping, resting. Here I can pray together on time, at home, not necessarily. If my shop was open, I couldn't conduct my prayer on time. If my son, who is a teacher, has returned from work, then I can pray and rest.
Time flew. Suddenly it was afternoon, and it was evening. Not to mention being bothered by a grandchild, asking for meals, snacks, and others at my house. It's different here. It's organized. At twelve o'clock at night, I wake and conduct the night praying while waiting for Bu Nyai to come. Later on, we recite the Quran. After that, usually, I cook, boil water, or wash clothes. When I get tired, I rest again. I wake up at dawn and stay up until the night to recite the Quran" (AM santri interview, 15 September 2018).

Similar experiences also come from SR (72 years old) who spent time in Pondok Sepuh to improve her value in God's eyes. In addition to performing the obligatory prayers, SR also did sunnah prayers and recited the Quran in order to correct her mistakes in the past. Sunnah prayers that SR often do were the six rak'ahs of awwabin prayers to compensate for missing worship in the past. SR believed that performing the six rak'ahs awwabin sunnah prayers is equivalent to twelve years of worship. By returning to God's path and correcting all the mistakes from her youth, SR believed that God would forgive her mistakes if she worships earnestly.

\section{Increasing the santri's faith}

Spiritual empowerment was believed to increase the santri's faith. Initially, the santri did not fully understand their religion. After participating in spiritual empowerment activities, the santri have now become more aware of the Islamic teachings, which has changed their attitudes and actions for the better. Santri MS, who was 75 years old, revealed that her motivation to stay in Pondok Sepuh was to study Islamic teaching (recite the Quran) and be able to worship regularly in the congregation. At home, she could not recite the Quran because no one taught her. She also spent much time with her grandchildren, so her opportunity to study religion was very minimal. After living 
in the pesantren, MS experienced a change in her life. Santri MS admitted that now she can recite the Quran even though she is still being not fluent. In addition to improving her Quran recitation skills, now MS always do the mandatory collective prayer.

When she entered Pondok Sepuh, MD actually could read the Quran fluently. MD only needed to learn to read correctly following the tajwid. This fact distinguished MD from other Santri/informants. MD spent her day participating in various religious activities, including Quran recitation, mandatory and sunnah worship, as well as fasting. In fact, MD often joined the Quran recitation and studies around the Payaman communities. MD was aware that even though she could recite the Quran, her time to study the Quran is often overlapped with her busy schedule with family. So, in accordance with her husband's will, MD felt that the best way to spend her old age was to gain God's blessing to be able to reunite with her late husband in heaven.

\section{Santri could recite Quran and the book of Ibris}

This impact is quite apparent. Santri who were previously could not read the Quran became able to read in accordance with the tajwid. In fact, some santri was also able to recite and interpret the book of Bris in the Javanese language. This was confirmed by the story of SR who came to Pondok Sepuh about five years ago. When she came to Pondok Sepuh, Santri SR did not understand the reading of hijaiyah letters. She came to Pondok Sepuh because of her strong determination to study religion, even though at first, her family did not approve. They thought that Pondok Sepuh was a nursing home. However, after learning that Pondok Sepuh was actually a special pesantren for the elderly, her family agreed with SR's decision to join Pondok Sepuh.
SR's experiences did not stop there. When she joined Pondok Sepuh, SR could not read the Quran immediately. SR learned to recognise hijaiyah letters first through Iqra. After about five years of study, SR was finally able to read the Quran. However, SR felt that she was still behind other santri because she had difficulties remembering the hijaiyah letters. So, she needed to repeat certain some readings continuously. In fact, her shortcomings made SR more motivated to keep learning to read until she can read it easily and effortlessly.

In contrast to SR, ED was new santri in Pondok Sepuh. She has been living there for approximately three years. ED joined Pondok Sepuh because of her daughter wished her to be able to recite the Quran. The daughter looked for information and found Pondok Sepuh through pesantren kilat program in the month of Ramadan. In the beginning, ED admitted that she came to Pondok Sepuh in a state of not being able to recite the Quran at all. However, during her stay at Pondok Sepuh, she made quite a progress. Currently, ED was able to read the Quran easily, even though her recitation was sometimes inaccurate. In fact, when there were guests who came to visit and ask questions, ED was always chosen by other santri to be their representative. ED was considered apt in conversation. The following was a statement from ED:

"My daughter told me. She said there is an independent Pondok Sepuh, so it's okay to go by myself. I arrived during Ramadan fasting, and my daughter signed me up. After she was invited by Ms DR, she said, 'what would you do at home?' Then I came here until now. ...I am still learning the Quran now. I am grateful because when I got here, I had zero knowledge. I didn't know anything. Now, I can read the Al-Quran, praise is to Allah" (interview of santri ED, 11 September 2018). 
Meanwhile, santri MD who had lived in Pondok Sepuh for about ten years, had different experiences. She joined because of her husband's will. MD was a santri who can easily understand the Quran. MD's ability to understand the Quran was apparently supported by her husband's background as a teacher of the Quran in her village in the past. In fact, her joining Pondok Sepuh was due to her husband's will in which he wished MD to study Islamic teaching in a pesantren. After studying religion at Pondok Sepuh, MD succeeded in reciting the Quran for many times. Now, MD studies the book of Ibris (the commentary book in the Javanese language). In fact, MD claimed not to have difficulty understanding the reading in the book of Ibris.

\section{Developing humanity among members}

This benefit was evident from the lives of santri, which exhibited mutual cooperation. Sharing is the hallmark of the santri who live in Pondok Sepuh. According to AM, in Pondok Sepuh, Santri were taught to share. Bu Nyai taught anyone who has completed the Quran to share their knowledge as much as possible with others. Therefore, what they have learned becomes a blessing. So, in Pondok Sepuh, santri who completed the Quran or get other blessings would share or offer some of what they have. AM, MS, and MD claimed that every time they returned from home, they would bring souvenirs for other santri, either in the form of basic needs, snacks, or vegetables. The following is a statement from santri AM: "...If I go home, it is the same. Usually, my child bought snacks. If not, vegetables will be given for free at the pesantren. People gave me gifts, so if I don't give it back, I feel embarrassed" (interview with AM santri, 15 September 2018).

Meanwhile, santri SR and ED often gave money. They worried that not all santri would like the food they brought.
Meanwhile, money could be used by other santri to buy what they need because not all santri always get timely transfers from their family. Another exhibition of cooperation in Pondok Sepuh was when MS santri borrowed money from her friend because her child could not visit her. She had to borrow money from other santri for her living expenses in the pesantren. The caregivers taught the elderly santri to not only help in the Pondok Sepuh environment. They were also taught to help others outside the pesantren complex, for example, by visiting and praying for the sick such as the Kyai, other santri's families, and the neighbouring communities close to Pondok Sepuh. In addition, they were also taught to offer their condolences if a member of adjoining communities dies.

\section{Fostering new relations}

Relationships existed not only between santri but also between santri and kyai. The formation of these new social relations had a positive impact on santri. This relationship caused santri to gain new social networks and still be able to maintain their existence in society. Santri MD experienced such thing. MD had similar goals and motivations as her friends. She wanted to study religion so that she could die husnul khotimah. Due to common goals and motivations, MD often exchanged information about the Quran study and completion outside Pondok Sepuh. In fact, sometimes MD and other santri were also asked by the Kyai to join the Quran recitation in the Kyai's house. Furthermore, by joining Pondok Sepuh, the santri also knew the santri from various regions. The following is the explanation from santri MD:

"I usually start at one o'clock. I wake up then go to the mosque for the midnight prayer, hajat and witir. In the afternoon, I recite the Quran at Bu Nyai, the wife of the Kyai's house. At Bu Nyai's I read other books. After Ashar prayer, I 
did sorogan briefly. Later, santri who are fasting are getting ready for their breakfasting. If you go to the pesantren here every Monday and Thursday, people must be fasting. Tomorrow is 10 Muharram, Pak Kyai recommended fasting. Wednesday or Friday nights, there is Quran completion. Every Monday, there is a recitation. There were santri coming from all over. We had different Kyaibutstill within Mbah Siradjfamily" (interview of santri MD, 11 September 2018).

\section{Spiritual Empowerment as an Alternative to Reducing Anxiety in the Elderly}

Death is one of the crucial mental health problems for the elderly (Azizah, 2011). In fact, it is not uncommon for death to be frightening for most elderly people (Santosa \& Ismail, 2009). To reduce the level of anxiety in facing death, some elderly has their own way to deal with it. They used the resignation method (surrender fully to God) through spiritual empowerment at Pondok Sepuh Payaman Magelang. The resignation method was carried out by santri for more than 12 hours. The average santri would wake up to perform the evening prayer at $01.00 \mathrm{WIB}$ and end their activities at 20.00 WIB or 21.00 WIB.

Based on these facts, the santri break time was only about three to four hours. However, santri did not feel forced or burdened by the activities at Pondok Sepuh. In fact, the learning method adopted by Pondok Sepuh spurred the spirit of santri to continue worshipping Allah. Santri followed many spiritual empowerments in Pondok Sepuh with much enthusiasm. Their enthusiasm was evident in their every activity, both ritual worship and social worship. In ritual worship, for example, obligatory prayers, santri always tried to do it in the group. In fact, the santritry not to miss the first takbiratul ihram by the imam for 40 consecutive days. This was done so that the santri could be freed from two things: the torments of hellfire and hypocrisy. Hadith continued to be used as a way to familiarize and raised santri's awareness. Thus, santri realized that they had to do something to amend their past mistakes. The hadith was able to make santri aware and give everything to God Almighty.

The use of hadith was also apparent in mind and heart of the santri. They developed strong motivation arises to worship only Allah. In addition to the mandatory prayers, santri were also encouraged to fast, attend studies, and perform sunnah worship to improve their lives. This was done as an effort to approach transcendent life. The santri believed that the Creator could be approached by performing rituals that were considered sacred, such as the mandatory prayer, sunnah prayer, fasting, reading the Quran and Ibris, and by following Islamic studies in general.

In addition to ritual worship, santri also carried out social worship because humans cannot live alone. Social worship was also carried out by santri to get closer to God. Santri believed that by doing something good and beneficial for others, they, as well as their environment, would give off a positive aura. The santri also believed that God was very close and loved goodness. So, they must keep doing good deeds to others as long as they did not hurt others. All efforts made by santri were only to gain the blessing of God Almighty. There was nothing else to expect, other than dying in husnul khotimah and getting forgiveness from God Almighty. The santri no longer want material things. They just wanted to die in a husnul khotimah and meet their Creator.

Death in husnul khotimah was the greatest goal of the elderly santri. They hoped that by participating in spiritual empowerment at Pondok Sepuh, all their past mistakes and sins would be forgiven by Allah. So, when their time of death comes, the santri was ready to meet with their Creator. In order to achieve this, the santri were willing to live 
separately with their relatives to participate in spiritual empowerment at Pondok Sepuh. Now, they tried not to leave the ritual, and social worship recommended by Pondok Sepuh and give everything for God. Spiritual empowerment for elderly santri in Pondok Sepuh had a positive impact on the lives of santri. It guided them in a better direction and showed that it could reduce mental health problems (anxiety) in the elderly in facing their death.

The findings of this study indicated that the elderly in Pondok Sepuh could be considered successful in undergoing old age. This phenomenon is in line with the theory of social gerontology, namely disengagement theory, which stated that the elderly could be said to be a successful life when they are able to withdraw from previous activities and choose to focus on the coming of death (Hillier \& Barrow, 2010). By becoming a santri in Pondok Sepuh, elderly women can resume their activities even though it is different from their previous activities. The disengagement theory emphasized that to maintain self-esteem, the elderly does not need to maintain the same activities. Instead, they can choose other activities while still focusing on the coming death. Furthermore, based on disengagement theory, when the elderly is able to reduce their previous activities and approach the Creator, the elderly can avoid depression and increase self-satisfaction (Hillier \& Barrow, 2010).

This study reinforced the findings of research conducted by Ownes et al. in 1994 on migrants living in America. This study stated that migrants (Hispanic groups) who lived in America such as Cuba, Mexico, Puerto Rico descent who believed in religion were able to handle life's problems (Stolley \& Koenig, 1997). This research's findings also reinforced the results of a study by Nurhidayah et al. which showed that a spiritual approach to the elderly in Karanganyar and Surakarta could help with depression rate. Conversely, elderly who had low of spirituality tend to experience stress because they focus on the quality of life (Nurhidayah et al., 2018)

Spiritual empowerment at Pondok Sepuh was also able to provide new activities for the elderly. In fact, they now carry a new status and role in society, even though it was different from their previous status and role. With their new status and role, the elderly women in Pondok Sepuh increase their social interaction in the community. This activity could also reduce mental issues, such as anxiety, depression, and stress. The findings of this study supported Singh and Upadhyay's research which found that the lack of social interaction among the elderly was caused by decreased hearing, vision, mental, intelligence, memory and also because of retirement. These factors could increase depression in the elderly (Singh \& Upadhyay, 2014)

Indirectly, spiritual empowerment at Pondok Sepuh made to embrace new function in society. First, the elderly could normally be active with a new status and role in society. Second, the elderly could still interact with their environment and be in the same community. Third, the elderly realized that they were no longer young, and death was coming. Therefore, getting closer to God almighty was a way for them to return to their Rabb. From this analysis, the elderly who take part in spiritual empowerment at Pondok Sepuh could be categorized as successful elderly. This statement was based on the concept of successful ageing for the elderly which covered physiological, psychological and social aspects (Martinson \& Berridge, 2015).

\section{Conclusion}

Pondok Sepuh was one of the new social spaces that could be an answer for the community and government in overcoming the problems of the elderly related to the 
decline in the mental health of the elderly. In old age, the elderly need spiritual empowerment to get closer to the Creator. This was done as an effort to reduce the level of anxiety of the elderly caused by decreased physical, social and mental functions. In old age, death also becomes a severe problem for the elderly. Thus, their spiritual empowerment was an important aspect that must be considered.

Pondok Sepuh had shown that even in old age, the elderly could still function in society even though their status and roles were different from their previous status and role. Spiritual empowerment implemented by Pondok Sepuh could help the elderly to refunction again in the community. The elderly could actualize themselves by carrying out social interactions that can increase selfsatisfaction. The findings of this study also confirmed that the mental health of the elderly could be maintained by involving social institutions such as pesantren and religious leaders. This approach is still very uncommon and can be a new step for the government, together with the community, to provide new and more comfortable social spaces in accordance with the needs of the elderly. Therefore, the elderly can achieve successful ageing, not only in terms of physical, social, but also mental and spiritual.

\section{Acknowledgement}

The researcher would like to thank the Pondok Sepuh Payaman Magelang extended family, who agreed to permitted data collection from September 2018 until finish. The researcher also expressed gratitude to Gadjah Mada University for providing the opportunity to continue the degree. The researcher thanks to all parties who could not be mentioned one by one who contributed to the writing of this article.

\section{Declaration of Ownership}

This article is our original work.

\section{Conflict of Interest}

There is no conflict of interest to declare in this article.

\section{Ethical Clearance}

This study was approved by the institution.

\section{References}

Azizah, L. M. (2011). Keperawatan lanjut usia. Graha Ilmu.

BPS. (2018). Statistik penduduk lanjut usia 2017. BPS.

Damanik, N. O. (2014). Pelayanan sosial lanjut usia (studi kasus pada enam orang warga binaan sosial di upt pelayanan sosial tuna rungu wicara dan lanjut usia Pematang Siantar. Jurnal Welfare State, 2(3), 1-12.

Dewi, S. R. (2014). Keperawatan gerontik. CV Budi Utama.

Jalaluddin. (2011). Psikologi agama. Grafindo Persada.

Kwon, S., \& Billiot, A. (2018). Elderly native American's mental health impacts of exposure to environmental changes. Journal Innovation in Aging, 2(1), 653654. https://doi.org/10.1093/geroni/ igy023.2437

Martinson, M., \& Berridge, C. (2015). Spesial issue: Succesfull ageing. Journal The Gerontologist, 55(1), 58-69. https://doi. org/10.1093/geront/gnv002

Nurhidayah, N., Syamsulhadi, M., Anantayu, S., \& Probandari, A. (2018). Psychosocial factors and leisure perception of the elder in two districts Central Java Indonesia. Journal Ageing International, 30(10), 1-9. https://doi.org/10.1007/s12126-018-93395 
Parkar, S. (2015). Elderly mental health. Journal Mens Sana Monographs, 13(1), 91-99. $\quad$ https://doi.org/10.4103/09731229.153311

Rahardjo,M.(2017).Studikasusdalampenelitian kualitatif konsep dan prosedurnya. http:// repository.uin-malang.ac.id/1104/1/ Studi-kasus-dalam-penelitian-kualitatif. pdf.

Rani, K., \& Usha. (2018). Disorganisation in social gerontology. Journal of Gerontology $\mathcal{E}$ Geriatric Research, 7(2), 466. https://doi. org/10.4172/2167-7182.1000466

Ryadi, A. L. S. (2016). Ilmu kesehatan masyarakat. Andi Offset.

Santosa, H., \& Ismail, A. (2009). Memahami krisis lanjut usia. Gunung Mulia.

Singh, R., \& Upadhyay, A. (2014). Mental health of elderly people. Journal of Psychosocial Research, 9(1), 61-70.

Stolley, J. M., \& Koenig, H. (1997). Religion/ spirituality and health among elderly African Americans and Hispanics. Journal of Psychosocial Nursing \& Mental Health Services, 35(11), 8-32.

Su, H., Cao, J., Zhou, Y., Wang, L., \& Lei Xing. (2018). The mediating effect of coping style on personality and mental health among elderly Chinese empty-nester: A cross-sectional study. Archives of Gerontology and Geriatrics, 75, 197-201. https://doi.org/10.1016/j. archger.2018.01.004

Sufa, I. G. (2013). Angka harapan hidup masyarakat Indonesia naik. Tempo News. http://nasional.tempo.co/amp/520055/ angka-harapan-hidup-masyarakatindonesia-naik.

Sunaryo, Wijayanti, R., Kuhu, M. M., Sumedi, T., Widayanti, E. D., Sukrillah, U. A., Riyadi, S., \& Kuswati, A. (2015). Asuhan keperawatan gerontik. Andi Offset.

Tamher, \& Noorkasiani. (2009). Kesehatan usia lanjut dengan pendekatan asuhan keperawatan. Salemba Medika.

UNFPA. (2009). Towards a society for all ages: Celebrating the 10th anniversary of the international year of older persons. http:// unfpa.org.

UNFPA. (2012). Ageing. https://www.unfpa. org/icpd/ageing, accessed in 12 January 2019.

Yasamy, M., Dua, T., Harper, M., \& Saxena, S. (2013). Mental health, a growing concern. WHO Report, 4-9. https://www. who.int/mental_health/world-mentalhealth-day/WHO_paper_wmhd_2013. pdf. 
Dwi Agustina 